\title{
Representations of Rural England in Contemporary Folk Song
}

\author{
Heather Skinner \\ Institute of Place Management, UK \\ heatherskinnercorfu@gmail.com
}

Purpose: This paper explores aural representations of the countryside and English rurality through the contemporary cultural product of folk song.

Methodology: A textual analysis was undertaken of the sleeve notes and lyrics of Steve Knightley, songwriter and founder member of the folk/roots band Show of Hands.

Findings: The concept of the rural idyll is thoroughly debunked in the majority of these lyrics. Many songs make specific reference to place, and these, in the main, focus on the historical and contemporary hardships of living in rural England, in many cases also making explicit reference to the historical or contemporary social issues deemed by the lyricist to be at the root of the problems faced by people living in English rural communities.

Research limitations: This article analyses data obtained in lyrics of only one songwriter within only one music genre, but the artist is one of the most respected within the contemporary folk genre, and Show of Hands have won a number of prestigious nationally recognised folk awards.

Originality/value: The extant literature contains little concerning aural representations of place identities through song. The contribution this paper makes is therefore in presenting a conceptual framework that shows how folk song, as a contemporary cultural product contributes to the construction and communication of rural place identities.

Keywords: Country life; Show of Hands; rurality; place identity; aural representation

\section{Research Paper}




\section{Representations of Rural England in Contemporary Folk Song}

\section{Introduction}

Popular music is known to influence peoples' thoughts and attitudes towards a subject (Leming, 1987), and a song can persuade people 'through narrative discourse, particularly through its lyrical content' (Smith and Jacobs, 2011:907), yet the extant literature has paid little attention to representations of places through song and the role aural representation, particularly through song lyrics, may have in the construction and communication of place identities. Moreover rural place identities remain under-researched compared with the urban, even within the place marketing and place branding literature (Greaves and Skinner, 2010), despite 'the symbolic value of a rural identity by which to market a place' (Bascom, 2001), a rural idyll based upon representations of rural scenery, availability of outdoor activities, and the opportunity for escape and relaxation (Greaves and Skinner, 2010). 'Englishness' is also a concept often presented as 'nostalgic, deferential and rural' and seen to be delivered 'by means of a potent array of educational and political instruments - ranging from the magazine Country Life to the folk-song fad to the National Trust' (Mandler, 1997).

It is these three constructs of the rural, Englishness, and place identity that together form the focus of this paper, which explores the way representations of rural England are communicated through contemporary cultural products, specifically in this case, through contemporary folk song. The contribution this paper makes is therefore in developing a conceptual framework that will offer a greater understanding of the role of a broadened range of contemporary cultural products to the construction and communication of place identities. In this case, specifically how rural England is represented in contemporary folk song. 


\section{Music and Place}

Music is 'a near universal and ubiquitous cultural expression' that can be seen to articulate not only identities, but also place and space (Lashua, Spracklen and Long, 2014:3). Music carries and conveys cultural and symbolic meanings, yet the way music production and consumption represents identity remains under-researched and under-theorised (Larsen, Lawson and Todd, 2010). 'Geography has the greatest claim on the study of places' (Parker, 2008:6). It is therefore somewhat surprising that Hudson (2006:626), discussing the 'strong links between music and sense of place and identities' also recognised a specific gap in the human geography literature in this respect. While 'the production of place through music' can be a 'contested process', music can play 'a very particular and sensuous role in place making' (Hudson, 2006:627). Indeed, Leyshon, Matless and Revill (1998:424-425) propose that music and place are 'mutually generative', and that 'to consider the place of music is not to reduce music to its location ... but to allow a purchase on the rich aesthetic, cultural, economic and political geographies of musical language.'

This is an important realisation when recognising that, otherwise, the way place identities are communicated tends to be a highly visual process with limited attention paid to other human senses (Medway, 2015), even though places can be represented aurally, with many locations being mythologised in song (Gibson and Davidson, 2004).

When issues of music and place have been addressed in the extant literature, with the notable exceptions of Gibson and Davidson (2004) and Edwards (2012) work, this research is often focused on urban places. Indeed, Edwards' research was specifically aimed at addressing a gap in the literature recognised by Gibson and Kong (2005:548) to analyse the cultural output 
of rural areas, thus addressing 'metropolitan primacy'. Lashua et al (2014:5) also stress that 'for scholars interested in musical geographies, the city remains a critical focus of questions of place, identity and - increasingly - cultural heritage', while Long (2014:48) cites various examples of "“world cities"' that have been featured in many song lyrics.

\section{Folk Music and Rural Places}

From its traditional historic roots, folk music has been 'wholly imbued with a sense of place, history and timelessness', connected to the rural, and the regional, with different identifiable musical styles and instruments found in the music of various regions of Britain (Connell and Gibson, 2003:35). Lena and Peterson (2008:698) define 'music genres as systems of orientations, expectations, and conventions that bind together an industry, performers, critics and fans in making what they identify as a distinctive sort of music', within which is folk music, identified as one of the specific seven streams of music (Ennis, 1992). Folk music as a genre is strongly linked to the concept of musical authenticity, that can potentially bridge the divide between the 'bourgeois' world of classical music that values talent and scholarship, and the 'commercial world' - whose 'raison d'étre' is 'turning sounds into commodities' (Wilson, 2011:167).

'The simplest definition of folk music is music that is orally transmitted between generations, within a culturally homogeneous community. It is typically thought to be of unknown origin. The idea of "folk" also suggests a rural community, and thus that folk music represents a survival of pre-industrial culture.' (Edgar and Sedgwick, 2008:127).

Edgar and Sedgwick (2008:127-128) believe such simplistic definitions are problematic not only because contemporary folk music 'is not necessarily of anonymous origin. Commercial 
popular songs were being incorporated in the "folk" tradition even in the nineteenth century'. Moreover, cultural anthropological studies in the mid-twentieth century questioned 'the association of "folk" with a more or less mythical rural past'. With regard to research into folk music, motivations for studying folk song are usually identified firstly, as being to preserve a cultural heritage, "a second motivation .... Was the recognition, within a number of European societies, that the recovery of a folk tradition could be important to the articulation of a national identity". Thus, folk song 'must be treated as much as an expression of political aspiration as a description of the way the cultural world really is'.

However, "in some quarters is still common to assume that "folklore" is a euphemism for moribund culture' (Brewer, 1994:5), with an alternative perspective that folklore 'is as likely to be found in contemporary city life as in isolated rural communities' (Brewer, 1994:6), and with folk songs associated with left-wing politics (Gibson and Davidson, 2004). Where 'the “new acoustic" folk-rock music' (Bell, 2006:150) can be seen as one source of mythologies concerning the rural idyll, claimed by Bell $(2006: 158)$ to be nothing more than 'a product of the bourgeois imaginary, worked up in the process of urbanization, industrialization and modernization' with the rural existing only in relation to the 'otherness' of the urban.

Yet when engaged in the marketing of tradition, representation of folklore 'appeals to a sense of communal heritage or traditionality touch powerful emotions because they go to the heart of individual, family, community and sometimes national or regional identities' (Brewer, 1994:7). Lomax (1959) also proposed that studies of folk song can aid not only a better understanding of the underlying values of various geographically situated cultures, but also that folk song, especially ballads in the 'Modern European' style that are rooted in a narrative tradition, can aid in contributing to the protection and preservation of those cultural values. In 
Latvia, for example, folk song was used to preserve a distinct Latvian cultural identity under Soviet rule (Bunksĕ, 1999) and later underpinned "The Land that Sings" Latvian re-branding campaign (Dzenovska, 2005). Researching folk and country music in Australia, Gibson and Davidson (2004) stress these genres are 'invariably set in rural locales'. (Clampin, 1999:67). also highlights that 'folksong was another means of signalling music's national credentials for composers in the early $20^{\text {th }}$ century. All over Europe folk melodies, folk inflections and the rhythms of "traditional" music found their way into symphonies and string quartets, imbuing work with "local colour". At the same time, many traditional folk tunes and lyrics were being preserved by the teacher, composer and music historian Cecil Sharp. However, his work has received some criticism of Bowlderisation for his publications of some of the bawdier lyrics he found, and also because:

'many of his misconceptions of rural communities and their culture have influenced a large number of collective notions as to what constitutes Englishness ... Sharp called for a return to the values folksong supposedly represented which perpetuated the myth of rural England, of the "good old days", a life before industry and commercialism' (Clampin, 1999:67-68).

\section{Rural England and issues of Identity}

Examining crime and illicit activity in rural England, Somerville, Smith and McElwee's (2015:219) research considers 'the dark side of the rural idyll', where such activities take place 'at the boundaries of enterprise and organised crime'. This article also provides a very useful comparison of constructions of rurality within the extant literature, recognising that the rural can be variously constructed: as the natural as opposed to the built environment; as a natural resource 'to be manipulated and reengineered to maximise profits for landowners and "agri-business", (p220); as cultural; as a material production of activity; as 'embodied 
practice', building on Lefebvre's notions of space and spatial practices; or as 'a multiplicity of ruralities and differentiated countryside'. It is this latter approach which Somerville et al (2015:221) see as a particularly useful construction because it can 'challenge the monolithic hegemony of other representations such as that of the rural idyll', and which also therefore facilitates considerations of rural places as somewhere crime and illicit practices can indeed occur. Yet even within the rural studies literature, the rural idyll continues to be a supported rather than contested construction. Somerville et al. also stress that when criminal or illicit activity is considered in rural places, those practicing such activities tend to be considered as 'rogues' rather than as the more perjorative term 'criminals'.

Pertinent to this paper is also that Somerville et al. (2015) recognise that much of the literature into rural places and the rural idyll relates to Britain. This would imply a need for some consideration into concepts of nationhood and nationalism, and the relevance of national and cultural identity (Skinner and Kubacki, 2007) to studies of music and representations of English rural identity. However, researching the concept of Englishness and English identity has been considered problematic due to the re-purposing of such concepts by extreme nationalist groups (Turner, 2000) and an association of, for example, the Union Jack flag being associated with a skinhead nationalist English culture (Brabazon, 1997), alongside a recognition that the non-white population of Britain tend to be largely excluded when defining the 'English' (Jacobson, 1997). Yet in the context of this paper it is impossible to ignore the concept of an English (rather than British) national identity, because Englishness and notions of rurality have long been intertwined (Wellings, 2007).

It is also pertinent to stress that this is specifically a feature of 'Englishness' rather than 'Britishness', or a feature of other of the national identities that have become more recently 
highlighted due to processes of devolution of government / parliament in the nations other than England comprising the United Kingdon of Great Britain and Northern Ireland (Brabazon, 1997; Kumar, 2003; Skinner and Croft, 2004). In terms of representations of an English national identity, it has been proposed, on the one hand, that 'English national identity cannot be found from within the consciousness of the English themselves ... We have to work from the outside in' (Kumar, 2003:17). However, from a critical perspective on place brand identity, this issue is better clarified from the understanding that it is place marketing that is enacted from an outside-in approach, ensuring that the place's 'single identity [although] with multiple facets' is managed via a 'market getting' approach, more akin to the management of the nation as a corporate identity (Skinner, 2008:923). The identity markers of a nation are understood to include popular culture, and the communicators of a national brand include music and the outputs of the arts and entertainment industry. Indeed a national identity itself can itself be viewed as a cultural product that communicates meaning to those that consume it (Skinner and Kubacki, 2007), and which can be researched from a study of cultural productions (Jacobson, 1997). Thus the branding of a place, the communication of a desired place brand identity, is actually an inside-out approach (Skinner, 2008:924). While 'the geographical place already exists, and so at the very core of the place brand are its natural and physical environmental elements ... Political, historical, social and cultural elements also contribute to the essence of a place brand, help contribute to its differentiation from other place brands, and act as elements that confer identity upon those inhabiting the place. There are also sensory and symbolic elements that may encompass staged spectacles, and which may or may not be based on authenticity' (Skinner, 2011:288289), and which are created and communicated by those within, in this instance, the nation place. Thereby pointing to the defence of a research perspective that focuses on the way a national identity, and for the purposes of this paper, specifically its rural identity, is 
represented through cultural output, in this case through song lyrics. Although it is also recognised that not all cultural representations of national identity are authentic, with some representing a commercially manufactures 'fakelore' rather than folklore (Atkinson-Wells, 1994; Goulding, 2000; Skinner, 2011; Skinner and Croft, 2004), yet folk music as a genre tends to have stronger claims for being 'authentic' than other commercial forms of music production (Moore, 2002).

\section{Method}

A call for 'new research methods and strategies', 'new forms of dealing with otherness in society', indeed 'some kind of methodological cosmopolitanism' that requires 'a shared critique of methodological nationalism' (Beck, 2007:286) is consistent with Brighenti's (2010:57) proposal that 'we need an epistemology that de-essentializes territories'. Thus Brighenti calls for use of narrative enquiry into places that he sees as constructed on narratives and myth. It would therefore seem appropriate to undertake a narrative analysis of the way representations of rural England appear in music, as these issues embody aspects of othering and nationalism, folklore, culture and myths. This is also consistent with the recommendations of Fillis (2011) to use narrative inquiry into arts marketing topics.

There is one paper in the extant literature that has considered 'the contribution of folk music to understanding the dynamic, fluid and multiexperiential nature of the countryside' (Yarwood and Charlton, 2009:194), and which also considers this in the context of the folk band Show of Hands. Yarwood and Charlton found limited attention in the literature to musical representations of the rural, being 'rather selective in its geography and genre, tending to focus on "mainstream", popular music in urban locations (Yarwood and Charlton, 2009:194). Their work examined the revival and development of folk music in England 'to 
examine the value of folk music to rural studies' (Yarwood and Charlton, 2009:195), in a paper that considers the musicians' origins and development of their musical style, analysis of live performances, and data drawn from interviews with the band members, rather than as this article will do, to undertake a systematic analysis of the lyrics of the band's songs in the context of how these represent rural England. This paper therefore takes a similar approach to Smith and Jacobs (2011:908) who used 'narrative analysis to explore the characterisations of accounting and the accountant that appear in popular music', based on the belief that 'music potentially offers an even more powerful insight into social perceptions and serves to not only reflect, but also create, these perceptions' (Smith and Jacobs, 2011:905).

When considering some of the issues relating to the otherness of the rural, and social inequalities that may be found when comparing rural with urban places, song lyrics are deemed suitable texts to be read from the perspective of 'critical literacy'. Analysis of the text of folk songs that are rooted in the rural, and written by someone who recognises the links between the lyrics he writes and the places he writes about could help address this power imbalance where those in power are the ones who generally choose what truths are to be privileged (Coffey, 2011). As the band stresses, 'being rooted in Devon and the West Country ... is part of the very fabric of this band and our material is closely entwined with its social history and geography' (Show of Hands - Facebook, 2015).

Textual analysis does remain a highly subjective method (Gibson and Davidson, 2004; Yarwood and Charlton, 2008). However, this type of analysis is often found in analysis of music, and there are six suggested parameters for song analysis that can help counter such inherent subjectivity: 'lyrics, melody, rhythm, harmony, form and production' (Fitzgerald, 2009:8). This paper will focus only on an analysis of song lyrics and, where provided, 
relevant sleeve notes about the songs or their meanings. Fitzgerald's paper focused on the artist (Brian Wilson) and his US Top 40 Hits, to provide a 'detailed examination of some of the work that established his reputation' thus Fitzgerald's research also included a 'systematic analysis of the songwriting and producing techniques that lie behind these works' and not specifically only on the content of his songs (Fitzgerald, 2009:1) and what Wilson's lyrics were representing. Based on the understanding that it is usually the lyrical content that is the most persuasive element of a song (Smith and Jacobs, 2011), the analytical focus of this paper, resting on only one of the parameters identified by Fitzgerald, facilitates a clearer analysis of aspects of these songs most relevant to this research aim, of exploring the way rural England is represented aurally through contemporary folk song lyrics.

The data source purposively chosen for this analysis is the catalogue of song lyrics of Steve Knightley, a songwriter in the English narrative tradition, and founder member of Show of Hands, who 'have emerged as one of the most successful roots bands in England' (Yarwood and Charlton, 1999:197). These lyrics come from the 16 CDs released between 1999-2011 and include Steve Knightley's lyrics performed with Show of Hands from 1987 but which had been previously released only on cassette tape recordings. Thirteen of these CDs are Show of Hands CDs, three are CDs performed as a solo artist, although some songs appearing on his solo CDs also appear on either earlier or later Show of Hands CDs. (The CD Wake the Union, released in 2012, was excluded from this data set because it had a particular focus on American folk music, including a song written by Steve Knightley to celebrate the work of the folk musician, with the Cecil Sharp Project, and otherwise all other relevant songs had already been included on previous CDs). 
A justification for purposively choosing this dataset is based on the popularity and reputation of the band, and the recognition accolades and awards they have received. Show of Hands' Facebook page recently noted their music had reached 'No. 1 in the Indy Breakers Chart; No. 1 on Amazon for English Folk' (Show of Hands, Facebook 2016), that they are also 'triple winners at the BBC Radio 2 Folk Awards where they have won the coveted categories Best Original Song, Best Duo and Best Live Act' and the musicians were awarded honorary doctorates from Plymouth University, with the University's interim Vice-Chancellor Professor David Coslett stating these awards were to mark 'great distinction in your professional lives ... musicianship, considerable national reputation and, through your music, celebration of place and use of narrative' (Show of Hands, Facebook, 2015).

\section{Discussion of Findings}

Most of the Steve Knightley and Show of Hands CDs included a mix of traditional and original songs. Only original songs were included in the analysis. Original instrumental tunes with no lyrics were immediately excluded from the analysis. Where different versions of the same song exist (e.g. Are We Alright / Tout va Bien; Crooked Man / Crooked Man '07) these were amalgamated into one piece of data for analysis. From $16 \mathrm{CDs}$ this left an initial data set of 110 lyrical songs. Most CDs included lyrics in sleeve inserts, but otherwise these were transcribed by the researcher. After an initial sift undertaken by listening to these songs and scrutinising lyrics for references relevant to representations of English rural identity, it was found that further songs could be excluded from the analysis: those about other places than England; songs about relationships and romance, where the rural landscape is referred to only in passing, or not at all; songs that did not specifically focus on the topic of this research. As an example, certain songs focused on the life of a professional musician. Songs such as Suntrap (focusing on a singer's summer season working abroad) were excluded from the 
analysis, others such as Last Picture Show and Be Lucky remained because they include themes relating to this research, especially about the impetus for people to leaving rural towns for better opportunities in big cities.

A qualitative method of thematic analysis of the narratives contained in the text of these lyrics was considered more appropriate for this study because this approach could identify themes arising from the data which may not have emerged through a quantitative approach that counted for example the occurrence of individual words or phrases. Defining the themes that started to emerge during the first sift through the songs, was an iterative process that continued throughout the research process. The initial, and then second sift, checking lyrics for relevance, resulted in a data set of 60 individual original songs (Table 1).

\section{Table 1: CDs, Songs and Themes}

Many of the songs mentioned specific places in the West Country, or referred to the region or counties within the region either within their titles (The Bristol Slaver; Widecombe Fair; Yeovil Town; Cold Heart of England) or within the lyrics (for example, Coming Home; Cousin Jack; Be Lucky). The sleeve notes of Lie of the Land (1995) situate each song to a particular place (for example The Hunter - Corscombe, Dorset; The Well - Upton Cross, Cornwall; The Keeper - North Tawton, Devonshire), and thus can be seen to be inextricably linked to these places (Connell and Gibson, 2003).

The rural idyll does not feature heavily in these song lyrics. Rather English rurality is typified by both historical and contemporary lack of opportunity, hardship and deprivation for those living in the countryside, in small towns and villages, and along the coast - a particular focus 
of many of these songs which are set in the West Country around Devon, Cornwall and Dorset. Thus these songs appear to feature a more real than bourgeois manufactured othering of the rural compared with the urban (Bell, 2006), and one that is more in keeping with multiple and differentiated constructions of rurality (Somerville et al., 2015). Moreover, such English rurality does not come across in these songs as particularly nostalgic or deferential (Mandler, 1997), the songs are more heretical in their challenge to the rural idyll.

\section{'Stuck in a one street town'/ leaving / returning}

The Last Picture Show is about a young man who aims to escape to the city and make his career as a professional musician rather than staying 'stuck in a one street town'. Sit you down speaks to someone who left his hometown and of the welcome he would get if he ever returned. There are echoes of this in Hard Shoulder where the singer sees an old friend who had left to seek better opportunities, while the singer remained in their home town. There are many other songs with the theme of leaving the small town to make a living: Friends tells that 'circumstances broke the spell, sent us all our separate ways'; in Beat about the bush, 'Jamie's heading for the big time he's going to move to town'. Leaving due to the lack of opportunity in traditional industry is mentioned in songs relating to contemporary issues: The Class of Seventy Three, where the class have all gone their separate ways when the mine closed down. 'Now the boys have all gone, but when we were young in the class of seventy three a miner was someone to be'. Running Away focuses on the problems of a young man who is 'led by the belt instead of the brain'. After a relationship break-up he returns to the West Country 'to fade into the countryside mix in with the rest', and finds manual work 'with my brothers on the hill'. 
Not everyone gets the chance to leave. The opening lines of Country Life tell of 'an everyday story of country life' for someone who 'talks of travel, never gets far'. Undertow considers the dreams of a young couple to escape their Devonshire lives 'we talk about America we dream of Spain, don't want another winter here in the English rain, we long for Australia ... might have been born here, no way we'll stay', but they remain in rural England, just like their friend remained, who stole a car to try to escape, but got caught 'trapped in the yard at the back of a Spar ... I found him left for dead'. In the end, everyone remains, no one escapes the undertow of rural life.

\section{Sailing to sea and/or going to war}

Other songs also focus on leaving, but where the impetus is sailing to sea or going to war. Columbus (didn't find America), Santiago, and Cousin Jack all tell of those who had to sail to foreign lands to seek their fortunes. Seven Days explains that 'it's the North Devon winters that drive us all to sea'. This theme recurs in Tall Ships. Sleeve notes explain that 'the story is set in a small West Country fishing village just after the Napoleonic Wars. The catch is meagre and the harvest fails. The villagers in desperation decide to wreck a passing Merchantman by placing a false light on the cliffs and tempting it onto the rocks. They succeed but among the drowned sailors they discover the body of a young man born and raised in the village. He had gone to sea a year before and was serving on board of the unfortunate ship'. In Tall Ships, the harsh winter and storms on the coast are seen from two perspectives: the local west country community who want the storm to wreck the ship, and the sailors' view of the storm as something that will aid the speed of their journey home.

Coming Home tells of someone who was 'born in the North country, raised in the West', someone who did not do well at school, and then 'all through this town he raised hell with his 
mates', slowing down this type of behaviour when he started dating and became a father, joined up to the forces (a common form of escape or career path for those from rural areas), until he is killed overseas where he 'fought with his brothers and served with the best', so now at only 'twenty years three months and a week' his body is being repatriated 'coming home'. The final lines of the song compare this contemporary loss of young life in warfare with a traditional focus 'since my bonny light horseman in the wars he was slain'. The Keeper also focuses on older wars, where the song's eponymous gamekeeper goes overseas to face enemy guns in France, then returns to Devonshire to walk towards the guns of the shoot that the keeper has to work on with the beaters to drive 'the birds towards the guns'.

Many of the songs in this theme related to historical topics and are written in a traditional narrative folk song style. For example, Drake is a song about Sir Francis Drake, originally from Devonshire, who circumnavigated the world, and led the English fleet against the Spanish Armada. Sleeve notes tell that The Bristol Slaver considers 'the notorious "three way trade" brought so much prosperity to the city that it was astonishing when the national coverage of Bristol's 1996 "Festival of the Sea" did not once mention the word slavery. This song is a small attempt to redress that imbalance". This appears to fit with the proposal that critical literacy theory applied to song can indeed help address imbalances where those in power are the ones who generally choose what truths are to be privileged (Coffey, 2011).

Armadas considers the life of a sailing man of war - first a sailor under 'the Duke de Medina' who commanded the Spanish Armada in the $16^{\text {th }}$ century; the next verse, about a sailor who travelled to the Malvinas who 'fought with General Menendez', the Argentine governor of the islands during the Falklands War between Britain and Argentina; the third verse sings about sailing to the Falklands under General Moore, British commander of land forces. 
Man of War is also written in the historic tradition of the English ballad showing some of the choices that were made for those who could not afford to remain living off the land, and makes comparisons between the way young people today may positively perceive the attraction of leaving a small town for opportunities in the armed forces.

The sea is also featured in Tall Ship Story about the stereotypical tall tales told by sailors. The Dive focuses on a dive taken during a contemporary fishing trip taken by a father and son, the song ends with that son considering the continuation of this family fishing business as he takes on the role of father to his own son.

\section{Social commentary on issues affecting rural communities}

Various traditional (including illegal) rural activities are mentioned in these songs, for example dowsing (The Well); sheep farming (Come By); hunting (The Hunter); gamekeeping (The Keeper); poaching (Longdog); sheep rustling (Transported); the Cheltenham Races (The Galway Farmer); country fairs (Widecombe Fair); Tin Mining (Cousin Jack); using 'red diesel', bartering, distilling homemade illegal alcohol (Red Diesel).

Some songs focus on specific places and specific issues relating to them: Cruel River tells a story in the narrative tradition of a young man who worked on a farm, where he fell in love with the owner's daughter, the family, not being happy about this, engaged the girl's brothers to teach the young man a lesson, whereupon the young girl broke away, but then lost her life by falling in the river. Sleeve notes acknowledge that this song is based on a local saying about the river Dart " "River of Dart, river of Dart, every year you claim a heart" a saying that even today still contains a tragic grain of truth'. 
The more general hardships faced by those living off the land in rural communities are also addressed: The effect of drought on rural communities is the focus of The Well, and this song also comments on the commodification and sale of water and other natural resources; in Come By, whereas once the shepherd could afford to live off the land, the singer asks: 'So where are the shearlings now to gather in the folds to count to clip and mark when there's no fleece to be sold. And when a life of learning skills out on these Western hills it barely pays the bills for a farmer'; 'Oh the fishermen rise with the sun and they work til the day's nearly done, hauling empty nets while the cold sun sets and the winter has barely begun' (Tall Ships - chorus). Man of War is not only about going to war, but about leaving your home, leaving the rural work you knew, leaving the land that could no longer support families who had worked on them for generations - 'when his father fell the land was carved. One piece for every son. There was barely enough for a family to feed. Hardly enough for one'. Country Life, an unashamed comparison between rural reality and the rural idyll as portrayed in the magazine of the same name, considers many of these issues, including that family farms face difficulties surviving in a commercial market of cheap food retailers, where foot and mouth disease caused more hardship for farms and others living in rural communities, the effect of the Common Agricultural Policy, of building on greenbelt land, and where there is limited infrastructure and little opportunity for work: 'no trains, no jobs, no shops, no pubs. What went wrong?'

As has been identified earlier, songs including Last Picture Show; Hard Shoulder; Undertow; Friends; Beat about the bush; Man of War; Seven Days; Cousin Jack also recognise that the impetus to leave ones rural home was often caused by hardship or deprivation. 
The way employment has changed for rural communities is also referenced. In Running away the young man who has returned to the West Country is forced to work off the books in the rural black market system. Sleeve notes to Cousin Jack noting the many thousands of Cornish tin miners who sought work overseas, state that 'with the threatened closure of South Crofty tin mine in Cambourne many more seem set to leave the country, finally bringing to an end two thousand years of mining in Cornwall'. The closure of mines leading people to seek employment elsewhere was also mentioned in Class of seventy three. One of the band's earlier songs, Ah So, centres on foreign manufacturing plants setting up in England. All Quiet on the Western Front considers the various changes in fortunes of parts of England, where, for example, in the North, heavy industry and manufacturing has been replaced by services, and in the South of England, where a strong agricultural tradition has been replaced by values more based on rising house prices.

Cutthroats, Crooks and Con-men is a song about cuts to public finding and privatisation of public services such as 'Power, Schools, Mines, Phones, Water, Health and anything else we used to own'. Privatisation of rail transport is seen as a particular problem in rural England, as is lack of materials in schools, selling off land to build houses and shops, and the privatisation of prisons - 'Cutthroats, crooks and con-men running this jail. Is there anything left in England not for sale?' Cold Heart of England examines the changes to the centres of small country towns. As the sleeve notes explain 'with the relentless rise of the global market the song could equally apply to the heart of any small community', with lyrics including that 'it's grey supermarkets instead of green fields to pay all our wages 'til we're choking in traffic and tied to the wheels like cattle in cages'. 
The importance of preserving a cultural heritage is to be found in a number of songs. Similar to The Oak, the chorus of Roots includes a metaphor of plant growth, 'seed, bud, flower, fruit, never going to grow without their roots. Branch stem shoots - we need roots' and a chorus in the style of a traditional sea-shanty to highlight the issue of loss of English cultural identity, 'we've lost more than we'll ever know on the rocky shores of England'. Roots was inspired by Steve Knightley hearing MP Kim Howells' view of folk music. The song contains the lyrics 'a minister said his vision of hell is three folk singers in a pub near Wells. Well I've got a vision of urban sprawl it's pubs where no one ever sings at all and everyone stares at a great big screen'. The song also tells of the way other cultures evidence their 'roots' through their folk music as a necessary as a way of connecting a culture's present to its past. 'Without our stories and our songs how will we know where we came from?' Englishness and folksong is therefore inextricably linked in this song, as is the way 'Englishness' has been claimed by extreme nationalists (Turner, 2000). 'I've lost St George in the Union Jack, it's my flag too and I want it back'. In acknowledging the erosion of English rural identity and ways of life the lyrics of some songs do provide a call to action to members of rural communities: 'Voices joined together will raise the country yet' (The Man in Green), thus also attempting to influence and persuade through these lyrics (Leming, 1987; Smith and Jacobs, 2011).

Much of the social commentary in these songs is aimed at political figures and their decisions that have affected rural English communities. There is a left-wing anti-Thatcherite slant to many of the songs released by the band in the late 1990s. Songs around this period cover issues relating to the Falklands War in 1982 (Armadas), and the build up to the 1991 Gulf War (Crooked Man). Whereas I promise you, appears on the surface to be a romantic song about what the singer promises his love once the winter is over, its meaning is that individuals could face a 'new dawn' once the winter of a Conservative government was 
replaced. Shadows in the Dark refers to the policy of 'Care in the Community', a Conservative party policy of 'deinstitutionalising' people that was brought in during the time of Margaret Thatcher's leadership, a theme echoed in Tommy, where a man with learning difficulties, living alone on the edge of society, commits suicide. Crooked Man is based on Tony Blair's claims of the existence of weapons of mass destruction that lead to the invasion of Iraq in 2003 - 'There was a crooked man with a crooked smile. He made a plan with a crooked file'.

Other songs compare historic with contemporary social issues: Columbus (didn't find America) compares America (that 'wasn't lost it was always there') at the time of its discovery, to today when 'the new world sickens and the old grows fat, might have been better if the world was flat'; Santiago sleeve notes explain the song tells the story of 'English relations with Chile going back over 200 years', lyrics including 'and when the country was torn how we chose sides, selling arms to the few to hold back the tide'; Transported compares the way contemporary criminals are treated relatively lightly with the way they would have previously been transported to Australia for even minor infractions of the law. Sleeve notes explain that Cold Frontier was written about 'how an ordinary Roman soldier would have felt about being posted to a "Cold Frontier" on the Tamar, the Tyne or the Dee. After more than three centuries here it must have seemed as if their world would never fade. Once again with a common currency and an almost border-free Europe we can share the same illusions'. Immigration and border issues are also included in The Flood: 'so let's stand on the white cliffs and look over to France, where hundreds are waiting for darkness to take one more chance'. The Bristol Slaver refers to the black community in St Pauls in Bristol, a consequence of the slave ship activities that departed England from Bristol docks. 
Other songs consider specific contemporary social issues. In Be Lucky, a song about a young musician leaving his rural roots to seek fame and fortune in London, lyrics refer to the TV talent show phenomenon. 'How much do you want the prize, will you freely sacrifice pride and your integrity for fortune and celebrity?' Safe as houses considers how people lock themselves away in their homes as a protection against crime, and as a result can lose human contact in a 'world of information sending static into space in communication but never face to face'. Whereas The Vale focuses on evacuees who were sent away from London during 1941 to seek safety in the countryside, White Tribes addresses the issue of warfare and that it can now so easily be conducted by 'warlords' with 'computers and ties around their necks, gunfire in the distance satellites above'. The Shout lauds volunteers and part-time members of local fire brigades and lifeboat crews, while questioning why others do not get involved.

Arrogance ignorance and greed $(A I G)$ sums up the effect on individuals of the global economic crisis, initiated by toxic debt and sub-prime lending by large corporations. In Wolf at the door there is reference to individual borrowing, and then those individuals getting into difficulty when repayment is required.

It's all your fault becomes a whole litany of the singer's woes - no responsibility is claimed, blame for all the singer's troubles is laid firmly at the feet of another. However, the final verse also includes wider environmental issues, for which the singer also takes no responsibility, 'it's all your fault' ... including the decline of the local town of Bridport.

Down in Hooke Forest they're chopping away

The ozone layer's getting thinner each day

I wrecked my car and lost my job

And Bridport's gone to the dogs

And it's all your fault 
Witness alludes to the idea of a promised land for those who live in the country with "no TV no net no phones no regret'. A nod is also given to the rural idyll in Raining Again, a song that considers the life of incomers to a rural English town, moving from London to find that, with reference to JRR Tolkien's books 'it's just like living in the Shire round here'. While change in rural English communities is most often commented upon in a negative light, in Windchanges there is a recognition that the wind has indeed changed for those living off the land in rural England, but also a recognition that there were problems for these people in the past, and many people from English rural communities identify with these places so much they would never leave.

\section{Crime / illicit activity / rogues}

Widecombe Fair sleeve notes identify this original song as 'an alternative, more sinister interpretation of the well known folk song "Widecombe Fair"', and parallels can be drawn between this version and the notorious Moors Murders of the 1960s.

Poppy Day tells of the insidious nature of the increase in drug use among young people in rural England, sung from the perspective of the London drug dealer. The song's title refers to the day the poppy (heroin) spreads to rural towns 'strike up the band today is poppy day, coming to a town near you'. Poppy Day is also the colloquial way of referring to Remembrance Sunday, where poppy buttonholes and pins are sold in aid of forces charities. Sleeve notes to this song explain that it is 'such a bitter irony that the flower that brings such comfort and relief is also the source of so much misery'.

Safe as Houses refers to crime rates that lead people to lock themselves safe away in their homes. Yeovil Town is based on a true event that happened to the band after a gig where they 
were on the receiving end of threatening behaviour of a man they encountered in a chip shop late at night.

Even the worst of crimes are justified in some of these song lyrics. For example, in Tall Ships, the deliberate shipwrecking of a merchantman that leads to loss of life, including the life of a member originally from the same rural community, is justified through easing the community's winter hardship. This shipwreck compares with that told in the song The Napoli, where, in 2007 the eponymous ship was deliberately broken up after it got into difficulty and was beached at Lyme Bay. Sleeve notes explain that 'the good folk of East Devon and beyond turned feral at the thought of what might get washed ashore off the decks of a stricken container ship'.

Lyme Bay to eBay tell me where's the sin

Everyone's a wrecker 'neath the skin

Come gangs from the North lads off the moor Wreckers on the cliff come down to the shore Scratch Joe Public what's underneath A looter and a pirate and a thief

Other lower level illicit acts are also included in these songs. The young man who returns to the West Country in Running Away works cash-in-hand, however, this means that while he has cash he has no access to the formal banking system 'couldn't even write a cheque, filled my boots with cash, in debt up to my neck'. The character of Terry in Red Diesel also would 'rather be paid in cash or kind, keeps his money in his pocket and never in a bank' and avoids tax because he 'writes all his records in his mind', also engaging in illegal alcohol distillation. 
Illegal activities often specifically associated with rural areas include poaching (The Keeper; Longdog) and sheep-rustling (Transported). Sleeve notes state that 'the poacher and his lurcher or Longdog in this story are an amalgam of various disreputable characters encountered in West Dorset over the last ten years or so'. Lyrics note that while the poacher who gets arrested and charged is given a 3 month jail sentence and a large fine, he acknowledges that 'half this town's had a real good time living on longdog's game'. Transported is a humorous song, based on a story the songwriter was told, where the singer and his uncle go sheep-rustling, they get a flat tyre, a policeman comes to help out. In order to escape arrest the uncle, telling the policeman he's calling for roadside assistance, instead 'dialled triple nine, said help me I'm stuck at the scene of a crime, a gas station robbery a mile down the line, come quickly, I'm trapped in the gents'. As with traditional narrative folk songs, the final verse provides the 'moral' 'so come you West country villains when you set out to steal, keep your phone charged, always check your spare wheel, and if you get caught use your wits not your heels, think of my uncle and me. Cos somewhere some copper he's just hopping mad, some farmer is counting more head than he had, and we're in the pub with our pints really glad we weren't born in 1803'.

This all seems to bear out Somerville et al's (2015) notions of the dark side of the rural idyll, where illegal and illicit activities take place, and where in the main, those engaged in such activities are considered more as 'rogues' (even loveable rogues) than 'criminals'.

\section{Tourism}

Due to the band's unnerving encounter with a local man in a chip shop in the town after a gig, Yeovil Town ends with the lyrics 'Don't tempt fate, never eat late and stay away from Yeovil town', although sleeve notes clarify while 'this incident actually happened, but it should not 
put anyone off visiting the town after dark. Red Diesel notes a local inhabitant's attitudes to grockles (the derogatory term used for tourists): 'Later in the bar said there ought to be a law keeping out the yuppies and the grockles (and the French)'. Cars compares the ideal of a daytrip to the coast with the reality of traffic jams as urban dwellers all head there.

\section{Exchange}

The theme of 'exchange' in these songs harks back to themes of magic, exchange, promises etc often found in older folk songs. The Hunter is ostensibly a song about hunting rights, but includes lyrics about what aspects of our ways of life we trade for votes, especially to those rich landowners who have the rights to the land, and also stand for parliament. In Be Lucky the musician visits a fortune teller that informs him 'if you want your music sold you should be smart or lucky ... make friends or money, but if you would be King be cruel'. After his big win at the Cheltenham Races, the Galway Farmer promises 'never again I'll chance my arm or cross the sea to England'. With echoes of this song, The Bet is about the way longshots may seem to come off, but sometimes there is a price to pay (again, in the narrative tradition, where nothing comes for free). A man takes a diversion off of the M5, places a bet, further down the road sees a car crashed lying on its roof in a field, goes to investigate, finds a suitcase full of money, calls in the accident but takes the cash, decided to launder the money by laying small bets all across the West Country. He wins big on the same longshot bet as the Galway Farmer on the horse Galway Bay, but on the way home from the races, his car crashes, and ends up lying on its roof in a field with the driver dead.

In the song Santiago lyrics note that 'we brought copper and ore, silver and gold, and in the mines and the fields the sweat of a people was sold'. Tall ships not only talks about exchange 
of labour for pay, but the exchange that is made in terms of guilt for wrecking a ship on which sailed a local man.

All they have to sell is the strength of two strong arms

All they own standing in their shoes

And the price of your labour in deep winter it falls and falls

The point came there was nothing left to lose

We pay the price of winter and we buy another year

The Well considers the rights of those who live on the land to access the natural resources of the land, and for these to not be the subject of commercial market exchanges. Cold Heart of England, and others such as Country Life and Roots similarly include issues of a rural past and a cultural heritage we have lost in exchange for what is deemed to be progress.

\section{Conceptual Framework}

Place brand identity comprises three realms: Territory (including geographical boundaries, and also a place's physical and natural environment); its economic, legal, political and cultural systems; and the symbolic and sensory elements that may be authentic or staged spectacles (Skinner, 2011). Such identities are created and communicated not from the outside-in as has been suggested by Kumar (2003), but rather from an inside-out approach (Skinner, 2008). The conceptual framework presented here (Figure 1) does not attempt to identify causal relationships between factors or variables (Jabareen, 2009). Rather, through a 'qualitative process of theorisation' (Jabareen, 2009:50), it attempts to focus only on concepts, and to identify how each of the concepts link together in order to further understanding of the issues identified in the paper, and to conceptualise representations of English rural identity in contemporary folk song. 


\section{Figure 1: Representations of rural England in contemporary folk music}

Figure 1: Representations of rural England in contemporary folk music

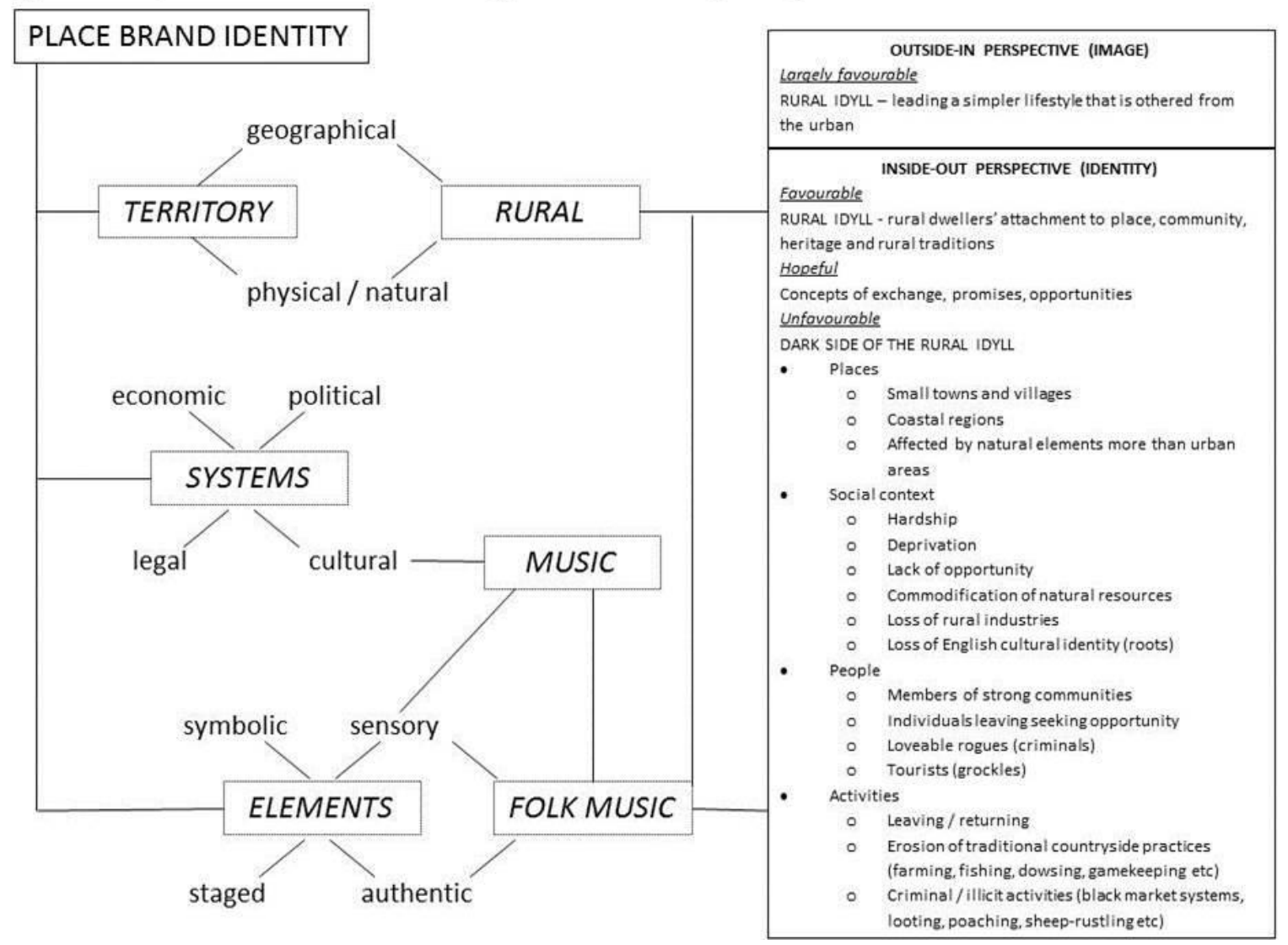

This framework shows how the concept of the rural links to a place's territory. Of specific relevance to this paper is that here, rurality tends to be linked to Englishness (Wellings, 2007), not Britishness (Brabazon, 1997; Kumar, 2003; Skinner and Croft, 2004), thus relating to: Nationhood and nationalism (Brabazon, 1997; Turner, 2000); national and cultural identity (Skinner and Croft, 2004); and focusing on one aspect of a nation's identity markers (Skinner and Kubacki, 2007) - the cultural outputs of a nation (Jacobsob, 1997; Skinner and Croft, 2004).

This framework focuses on one aspect of a place's cultural system, music. Popular music can influence and persuade; music carries and conveys meaning; contributes to place making (Hudson, 2006); acts an identity marker and communicator of place identity (Lashua et al., 
2014) including the identity of nations. Yet the way music communicates place identity has so far been under-theorised (Larsen et al., 2010), even within the geography literature (Hudson, 2006). Within the place brand literature there also remains a focus on visual rather than other sensory representations (Medway, 2015). When music and place have been researched this also tends to focus on the urban rather than the rural (Gibson and Davidson, 2004; Gibson and Kong, 2005; Yarwood and Charlton, 2009). A lack of focus on the rural is also a feature of the extant place branding literature (Greaves and Skinner, 2010).

This conceptual framework also recognises that folk music tends to be more connected to the rural rather than the urban (Edgar and Sedgwick, 2008). With respect to the other elements contributing to a place brand identity, folk music is perceived as authentic (Moore, 2002), tends to be political (Gibson and Davidson, 2004), it can preserve cultural heritage (Lomax 1959) not only through historic songs but also through contemporary songs in the narrative tradition (Brewer, 1994), and can also present contemporary culture with a critical often leftwing focus on the social issues facing rural communities.

English contemporary folk music also tends to perceive the cultural values of the rural as othered from the urban, and is considered a musical genre that contributes to a sense of national or regional identity (Brewer, 1994). The findings from this research, as presented in the conceptual framework, also identify that there is a mismatch between the place brand image (from an outside-in perspective), that focuses on the rural idyll, compared with the inside-out place brand identity, that focuses much more on the dark side of rurality, including crime, and illicit activity (Somerville et al., 2015); lack of opportunity, hardship, and deprivation facing communities in small rural towns and villages, including in coastal regions. Because of these specific hardships the song lyrics analysed also contained many 
themes of leaving and returning, loss of opportunity, of industry, of rural activities and traditions, and of an English cultural identity. However, even the inside-out identity perspective recognises that rural community dwellers do show a great deal of attachment to place and community, and to heritage and rural traditions.

\section{Conclusion}

The main and original contribution this paper makes is in therefore in developing and presenting a conceptual framework that shows how folk song, as a contemporary cultural product, contributes to the construction and communication of rural place identities.

However, based upon an understanding that this framework focuses on a place brand identity, further research could apply this general framework to: other types of place (territory); focus on other of a place brand's systems that cultural, and these systems' outputs, rather than, as has been undertaken here, to the (folk) music outputs relating to a particular nation's rural places. The framework as presented here could also be further explored in application to other music genres, or to other nations' folk music output.

The focus of this particular special issue is in a consideration of music, culture and heritage in developing marketing theory and practice. The specific focus of this paper has been to consider the way a particular type of music represents a particular type of place. This paper also indicates that this particular body of contemporary folk music can be considered to some extent heretical by challenging the image of the English rural idyll that is so often perceived from an outside-in perspective. In application to practice, as was stressed by Greaves and Skinner (2010), insights into various sensory representations of place from a wide range of 
sources need to be understood by those responsible for managing and marketing that place, including a place's representations in the arts and cultural industries.

In its consideration of the way representations of rural England are communicated through music as a contemporary cultural product that this paper fills an important gap in the literature on the way place identities are otherwise created and communicated (Medway, 2015). It is also of value because of its focus on the rural rather than the urban place, which has, to date been the main focus of studies into both the marketing of places (Greaves and Skinner, 2010) and research into place-located songs (Lashua et al., 2014).

The justification for a focus on folk music rests on the understanding that this genre has always been inherently connected to the rural (Connell and Gibson, 2003:35), and by considering rurality as a multiplicitous and differentiated construct (Somerville et al., 2015) this paper has also therefore taken a broader view of folk and folklore than may otherwise be found in the extant literature (Brewer, 1994). While folk music can be seen to be inextricably linked to the place in which it is produced (Connell and Gibson, 2003), this insight does not reduce the music in question to its location (Leyshon et al., 1998). This paper argues that music in general, and folk music in particular, is a cultural product that can carry meaning (Larsen et al., 2010) and represent identity (Lashua et al., 2014), in this case English rural identity. To do this, folk music does not have to be anonymous, traditional (i.e. old), noncommercial or associated with a mythical rural past Edgar and Sedgwick (2008), one that is based more on fakelore than folklore (Brewer, 1994). Contemporary folk song, whether written in a traditional narrative, or more contemporary style can be seen to be able to represent both historical and contemporary identities. 
While the rural idyll has been seen by Bell (2006) to be not only produced by the bourgeois world in an attempt at othering the non-urban, it may be that such contemporary music written and performed by such reputed and widely known folk artists may indeed provide a useful bridge between the bourgeois and the commercial world (Wilson, 2011). The concept of the rural idyll is thoroughly debunked in the majority of Steve Knightley's lyrics, very few of which make any positive references to the concept. Yet the concept of Englishness remains, and representation of English rural identity can be evidenced in these song lyrics, although it is a type of Englishness, that while remaining intertwined with notions of rurality (Mandler, 1997; Wellings, 2007) is no longer necessarily nostalgic, and most definitely not deferential.

\section{References}

Atkinson Wells, P. (1994) 'Marketing of Tradition: A New Approach' in: T. Brewer (Ed) (1994) The Marketing of Tradition: Perspectives on Folklore, Tourism and the Heritage Industry, Chippenham: Antony Rowe Ltd

Bascom, J. (2001) “"Energizing” Rural Space: The Representation of Countryside Culture as an Economic Development Strategy', Journal of Cultural Geography, 19(1), pp. 53-73.

Beck, U. (2007) 'The Cosmopolitan Condition: Why Methodological Nationalism Fails', Theory Culture and Society, 24, pp. 286-290.

Bell, D. (2006) 'Variations on the rural idyll' In: Cloke, P., Marsden, T. and Mooney, P.H. (eds) (2006) Handbook of Rural Studies, London: Sage 
Brabazon, T. (1997) 'Boot politics: Pondering the Antipodean Doctor Marten boot', Continuum, 11(3), pp. 59-73.

Brewer, T. (Ed) (1994) The Marketing of Tradition: Perspectives on Folklore, Tourism and the Heritage Industry (Folklore in use). Enfield Lock: Hisarlik Press

Brighenti, A.M. (2010) 'On Territorology: Towards a General Science of Territory', Theory, Culture and Society, 27, pp.52-72.

Bunksě, E.V. (1999) 'Reality of rural landscape symbolism in the formation of a post-Soviet, postmodern Latvian identity', Norsk Geografisk Tidsskrift, Norwegian Journal of Geography, 53(2-3), pp. 121-138.

Clampin, F. (1999) “"Those blue remembered hills ...”: National Identity in English Music (1900-1930), In: Cameron, K. (Ed) (1999) National Identity, Exeter: Intellect Books

Coffey, H. (2011) Critical literacy [Internet] http://www.learnnc.org/lp/pages/4437?style=print [date accessed 23 ${ }^{\text {rd }}$ July 2013]

Connell, J. and Gibson, C. (2003) Sound Tracks: Popular Music, Identity and Place, London: Routledge

Dzenovska, D. (2005) 'Remaking the nation of Latvia: Anthropological perspectives on nation branding', Place Branding, 1(2), pp. 173-186. 
Edgar, A. and Sedgwick, P. (Eds) (2008) Cultural Theory: The Key Concepts, $2^{\text {nd }}$ Edition, London: Routledge

Edwards, R. (2012) ‘Gympie’s country music Muster: Creating a cultural economy from a local tradition', Journal of Rural Studies, 28, pp. 517-527.

Ennis, P.H. (1992) The Seventh Stream: The Emergence of Rock-n-Roll in American Popular Music, Middletown, CT: Wesleyan University Press.

Fillis, I. (2011) 'The evolution and development of arts marketing research', Arts Marketing: An International Journal, 1(1), pp. 11-25.

Fitzgerald, J. (2009) 'Creating Those Good Vibrations: An Analysis of Brian Wilson's US Top 40 Hits 1963-66', Popular Music and Society, 32(1), pp. 3-24.

Gibson, C. and Davidson, D. (2004) 'Tamworth, Australia's “country music capital”: place marketing, rurality, and resident reactions', Journal of Rural Studies, 20, pp.387-404.

Gibson, C., Kong, L., (2005) 'Cultural economy: a critical review', Progress in Human Geography, 29(5), pp.541-561.

Goulding, C (2000) 'The commodification of the past, postmodern pastiche, and the search for authentic experiences at contemporary heritage attractions', European Journal of Marketing 34 (7) 835-853 
Greaves, N. and Skinner, H., (2010) 'The importance of destination image analysis to UK rural tourism', Marketing Intelligence and Planning, 28(4), pp. 486-507

Hudson, R. (2006) 'Regions and place: music, identity and place', Progress in Human Geography 30(5), pp.626-634.

Jabareen, Y. (2009) 'Building a Conceptual Framework: Philosophy, Definitions, and Procedure', International Journal of Qualitative Methods, 8(4), pp 49-62

Jacobson, J. (1997) 'Perceptions of Britishness', Nations and Nationalism, 3(2), pp. 181-199.

Larsen, G., Lawson, R. and Todd, S. (2010) 'The symbolic consumption of music', Journal of Marketing Management, 26(7/8), pp.671-685.

Lashua, B., Spracklen, K. and Long, P. (2014) 'Introduction to the special issue: music and tourism', Tourist Studies, 14(1), pp. 3-9.

Leming, J.S. (1987) 'Rock music and the socialization of moral values in early adolescence', Youth \& Society, 18(4), pp. 363-83.

Lena, J. C. and Peterson. R. A. (2008) 'Classification as culture: Types and trajectories of music genres', American Sociological Review, 73(5), pp. 697-718.

Leyshon, A., D. Matless and G. Revill (eds) (1998) The Place of Music. New York: The Guilford Press. 
Lomax, A. (1959) 'Folk Song Style', American Anthropologist, New Series, 61(6), pp. $927-$ 954.

Long, P. (2014) 'Popular music, psychogeography, place, identity and tourism: The case of Sheffield', Tourist Studies, 14(1), pp. 48-65.

Mandler, P. (1997) "Against "Englishness": English Culture and the Limits to Rural Nostalgia, 1850-1940', Transactions of the Royal Historical Society (Sixth Series), 7, pp 155-175

Medway, D. (2015) 'Rethinking place branding and the "other” senses', In: Kavaratzis, M., Warnaby, G. and Ashworth, G. (eds) Rethinking place branding, Switzerland:Springer International Publishing

Moore, A. (2002) ‘Authenticity as authentication', Popular Music, 21(2), pp. 209-223.

Show of Hands - Facebook (2016) [Internet] https://www.facebook.com/showofhandsmusic/?fref=nf [accessed $28^{\text {th }}$ January 2016]

Show of Hands - Facebook (2015) [Internet] https://www.facebook.com/showofhandsmusic/posts/10153540601719098 [Accessed 11th September 2015] 
Skinner, H. (2008) 'The emergence and development of place marketing's confused identity', Journal of Marketing Management, 24(9/10), pp.915-928.

Skinner, H. (2011) 'In search of the genius loci - the essence of a place brand', The Marketing Review, 11(3), pp. 281-292

Skinner, H. and Croft, R. (2004) 'Creating the Cool: Exploring the concept of national branding', International Journal of Applied Marketing, 3(2), pp3-21

Skinner, H. and Kubacki, K. (2007) 'Unravelling the complex relationship between nationhood, national and cultural identity, and place branding', Place Branding and Public Diplomacy, 3, pp. 305-316.

Smith, D. and Jacobs, K. (2011) “"Breaking up the sky”: The characterisation of accounting and accountants in popular music', Accounting, Auditing \& Accountability Journal, 2(7), pp. 904-931.

Somerville, P., Smith, R. and McElwee, G. (2015) 'The dark side of the rural idyll: Stories of illegal/illicit economic activity in the UK countryside', Journal of Rural Studies, 39, pp. 219-228.

Turner, G. (2002) British Cultural Studies: An introduction ( $3^{\text {rd }}$ Edition), London: Routlegde

Wellings, B. (2007) 'Rump Britain: Englishness and Britishness, 1992-2001', National Identities, 9(4), pp. 395-412. 
Wilson, N. (2011) 'The business of authenticity: a false relation?', Arts Marketing: An International Journal, 1(2), pp. 159-170.

Yarwood, R. And Charlton, C. (2009) "“Country life”? Rurality, folk music and "Show of Hands", Journal of Rural Studies, 25(2), pp. 194-206. 
Table 1: CDs, Songs and Themes

\begin{tabular}{|c|c|c|c|c|c|c|c|}
\hline SONG & CD & $\begin{array}{c}\text { 'Stuck in a } \\
\text { one street } \\
\text { town' / } \\
\text { leaving / } \\
\text { returning }\end{array}$ & $\begin{array}{c}\text { Sailing } \\
\text { to sea } \\
\text { and / or } \\
\text { going to } \\
\text { war }\end{array}$ & $\begin{array}{c}\text { Social } \\
\text { commentary } \\
\text { on issues } \\
\text { affecting } \\
\text { rural } \\
\text { communities }\end{array}$ & $\begin{array}{c}\text { Crime/ } \\
\text { illicit } \\
\text { activity } \\
/ \\
\text { rogues }\end{array}$ & Tourism & Exchange \\
\hline Ah so & Show of Hands Backlog 1987-1991 (1999) & & & $\mathrm{x}$ & & & \\
\hline The last picture show & Show of Hands Backlog 1987-1991 (1999) & $\mathrm{x}$ & & $\mathrm{x}$ & & & \\
\hline Friends & Show of Hands Backlog 1987-1991 (1999) & $\mathrm{x}$ & & $\mathrm{x}$ & & & \\
\hline \multirow{3}{*}{ Tall ships } & Show of Hands Backlog 1987-1991 (1999) & & $\mathrm{x}$ & $\mathrm{x}$ & $\mathrm{x}$ & & \\
\hline & Cold Cuts (2002) & & & & & & \\
\hline & The best of Show of Hands (2007) & & & & & & \\
\hline \multirow[t]{2}{*}{ The Hunter } & Lie of the Land (1995) & & & $\mathrm{x}$ & & & $\mathrm{x}$ \\
\hline & Show of Hands Live at the Albert Hall (1996) & & & & & & \\
\hline \multirow[t]{2}{*}{ The well } & Lie of the Land (1995) & & & $\mathrm{x}$ & & & $\mathrm{x}$ \\
\hline & Show of Hands Live at the Albert Hall (1996) & & & & & & \\
\hline The keeper & Lie of the Land (1995) & & $\mathrm{x}$ & $\mathrm{x}$ & $\mathrm{x}$ & & \\
\hline Safe as houses & Lie of the Land (1995) & & & $\mathrm{x}$ & $\mathrm{x}$ & & \\
\hline \multirow[t]{2}{*}{ The man in green } & Lie of the Land (1995) & & & $\mathrm{x}$ & & & \\
\hline & Show of Hands Live at the Albert Hall (1996) & & & & & & \\
\hline \multirow[t]{2}{*}{$\begin{array}{l}\text { Columbus (didn't find } \\
\text { America) }\end{array}$} & Show of Hands Live at the Albert Hall (1996) & & $\mathrm{x}$ & $\mathrm{x}$ & & & \\
\hline & The best of Show of Hands (2007) & & & & & & \\
\hline $\begin{array}{l}\text { Cutthroats, crooks and Con- } \\
\text { men }\end{array}$ & Show of Hands Live at the Albert Hall (1996) & & & $\mathrm{x}$ & & & \\
\hline Santiago & Show of Hands Live at the Albert Hall (1996) & & $\mathrm{x}$ & $\mathrm{x}$ & & & $\mathrm{x}$ \\
\hline & Show of Hands Live (1999) & & & & & & \\
\hline
\end{tabular}




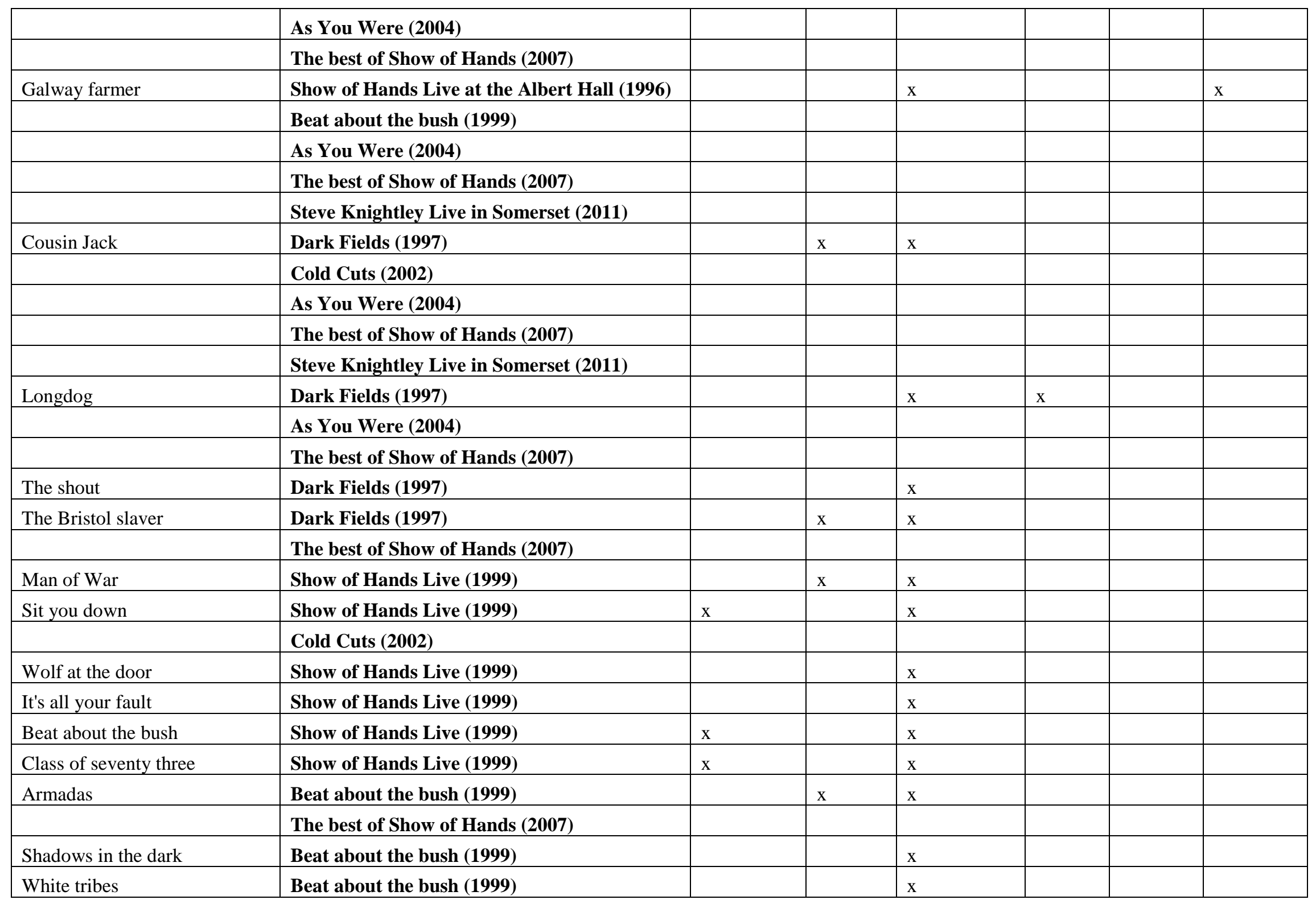




\begin{tabular}{|c|c|c|c|c|c|c|c|}
\hline Cars & Beat about the bush (1999) & & & & & $\mathrm{x}$ & \\
\hline \multirow{3}{*}{ The oak } & Beat about the bush (1999) & & & $\mathrm{x}$ & & & \\
\hline & As You Were (2004) & & & & & & \\
\hline & The best of Show of Hands (2007) & & & & & & \\
\hline \multirow{2}{*}{ Cold frontier } & Cold Frontier (2001) & & & $\mathrm{x}$ & & & \\
\hline & The best of Show of Hands (2007) & & & & & & \\
\hline Come by & Cold Frontier (2001) & & & $\mathrm{x}$ & & & \\
\hline \multirow[t]{3}{*}{ Widecombe Fair } & Cold Frontier (2001) & & & $\mathrm{x}$ & $\mathrm{x}$ & & \\
\hline & As You Were (2004) & & & & & & \\
\hline & The best of Show of Hands (2007) & & & & & & \\
\hline Windchanges & Cold Frontier (2001) & & & $\mathrm{x}$ & & & \\
\hline Yeovil town & Cold Frontier (2001) & & & & $\mathrm{x}$ & $\mathrm{x}$ & \\
\hline \multirow[t]{2}{*}{ Cold heart of England } & Cold Frontier (2001) & & & $\mathrm{x}$ & & & $\mathrm{x}$ \\
\hline & $\begin{array}{l}\text { Steve Knightley Track of Words retraced } \\
(2009)\end{array}$ & & & & & & \\
\hline The flood & Cold Frontier (2001) & & & $\mathrm{x}$ & & & \\
\hline \multirow[t]{4}{*}{ Country life } & Country Life (2003) & $\mathrm{x}$ & & $\mathrm{x}$ & $\mathrm{x}$ & & $\mathrm{x}$ \\
\hline & As You Were (2004) & & & & & & \\
\hline & The best of Show of Hands (2007) & & & & & & \\
\hline & Steve Knightley Live in Somerset (2011) & & & & & & \\
\hline \multirow[t]{2}{*}{ Hard shoulder } & Country Life (2003) & $\mathrm{x}$ & & $\mathrm{x}$ & & & \\
\hline & The best of Show of Hands (2007) & & & & & & \\
\hline Seven days & Country Life (2003) & & $\mathrm{x}$ & $\mathrm{x}$ & & & \\
\hline Tommy & Country Life (2003) & & & $\mathrm{x}$ & & & \\
\hline \multirow[t]{2}{*}{ Be lucky } & Country Life (2003) & & & $\mathrm{x}$ & & & $\mathrm{x}$ \\
\hline & As You Were (2004) & & & & & & \\
\hline Drake & Country Life (2003) & & $\mathrm{x}$ & & & & \\
\hline I promise you & Country Life (2003) & & & $\mathrm{x}$ & & & \\
\hline
\end{tabular}




\begin{tabular}{|c|c|c|c|c|c|c|c|}
\hline Red diesel & Country Life (2003) & & & $\mathrm{x}$ & $\mathrm{x}$ & $\mathrm{x}$ & \\
\hline \multirow[t]{2}{*}{$\begin{array}{l}\text { Crooked Man / Crooked Man } \\
\text { '07 }\end{array}$} & As You Were (2004) & & & $\mathrm{x}$ & & & \\
\hline & Steve Knightley Cruel River (2007) & & & & & & \\
\hline Witness & Witness (2006) & & & $\mathrm{x}$ & & & \\
\hline \multirow[t]{2}{*}{ Roots } & Witness (2006) & & & $\mathrm{X}$ & & & $\mathrm{x}$ \\
\hline & The best of Show of Hands (2007) & & & & & & \\
\hline The dive & Witness (2006) & & $\mathrm{x}$ & & & & \\
\hline Undertow & Witness (2006) & $\mathrm{x}$ & & $\mathrm{x}$ & & & \\
\hline The bet & Witness (2006) & & & & & & $\mathrm{x}$ \\
\hline Raining again & Steve Knightley Cruel River (2007) & & & $\mathrm{x}$ & & & \\
\hline Poppy Day & Steve Knightley Cruel River (2007) & & & $\mathrm{x}$ & $\mathrm{X}$ & & \\
\hline All quiet on the Western Front & Steve Knightley Cruel River (2007) & & & $\mathrm{x}$ & & & \\
\hline Tall ship story & Steve Knightley Cruel River (2007) & & $\mathrm{x}$ & & & & \\
\hline Cruel river & Steve Knightley Cruel River (2007) & & & & & & \\
\hline \multirow[t]{2}{*}{ Transported } & Steve Knightley Cruel River (2007) & & & $\mathrm{x}$ & $\mathrm{x}$ & & \\
\hline & Steve Knightley Live in Somerset (2011) & & & & & & \\
\hline The Napoli & Arrogance Ignorance and Greed (2009) & & & & $\mathrm{x}$ & & \\
\hline The Vale & Arrogance Ignorance and Greed (2009) & & & $\mathrm{x}$ & & & \\
\hline AIG & Arrogance Ignorance and Greed (2009) & & & $\mathrm{x}$ & & & \\
\hline Running away & $\begin{array}{l}\text { Steve Knightley Track of Words retraced } \\
(2009)\end{array}$ & $\mathrm{x}$ & & $\mathrm{x}$ & & & \\
\hline Coming home & Steve Knightley Live in Somerset (2011) & & $\mathrm{x}$ & $\mathrm{x}$ & & & \\
\hline
\end{tabular}

